\title{
MANUSIA DAN POTENSI PENDIDIKANNYA PERSPEKTIF FILSAFAT PENDIDIKAN ISLAM
}

\section{Pahrurrozi*}

\begin{abstract}
Abstrak: Manusia dalam perspektif Islam adalah hamba Allah dan khlaifah dimuka bumi. Manusia juga memiliki segudang potensi bawaan sebagai salah satu bentuk fitrah diri. Potensi bawaan inilah yang harus dilihat oleh pendidikan Islam untuk dikembangkan dalam pendidikan. Tulisan ini mengkaji tentang bagaimana filsafat pendidikan Islam melihat manusia dan potensi pendidikannya untuk dikaji dalam upaya pengembangan manusia seutuhnya.
\end{abstract}

Kata Kunci: Manusia, Potensi, Pendidikan, Filsafat, Islam

\section{Pendahuluan}

$\mathrm{D}$ alam menapak tilas ide-ide baru pendidikan Islam, para pemikir, pemerhati, dan pelaksana pendidikan saat ini harus mampu mengoptimalkan potensinya. Potensi yang dimiliki harus ditumbuhkembangkan dalam rangka mencapai tujuan pendidikan Islam. Berawal dari masalah-masalah yang membentur dunia pendidikan, khususnya pendidikan Islam. Maka filsafat sebagai sebuah aksi, berusaha mencoba untuk menjawab masalahmasalah tentang pendidikan Islam.

Masalah pendidikan merupakan masalah hidup dan kehidupan manusia. Proses pendidikan berada dan berkembang bersama proses perkembangan hidup dan kehidupan manusia. Banyak di antara masalah-masalah kependidikan tersebut yang merupakan masalah yang harus dijawab dengan menggunakan pendekatan filosofis.

Berbagai masalah tentang hidup dazn kehidupan umat Islam dari segi pendidikan memang merupakan tantangan bagi umat

* Dosen Luar Biasa UIN Mataram, Tenaga Pengajar, dan Wakil Ketua Yayasan Nurul Hidayah Juring, Lombok Tengah NTB. E-mail: pahrurroziojik9@gmail.com 
Islam untuk menjawabnya. Jawaban terhadap pertanyaanpertanyaan hakiki tersebut, akan menjadi dasar bagi pelaksanaan dan praktik pendidikan Islam. Ketepatan jawaban pertanyaanpertanyaan tersebut, akan mampu merumuskan tujuan pendidikan Islam secara tepat, dan hal ini akan mengarahkan pada usaha-usaha kependidikan Islam yang tepat pula. Di sinilah letak peranan filsafat pendidikan Islam (Zuhairini, dkk., 2008: 126-127).

Dalam proses pertumbuhannya, filsafat pendidikan sebagai ikhtiar dari para ahli filsafat atau para filosof berusaha mencari tahu tentang hakikat manusia dan potensi pendidikannya. Substansi dan potensi fitrah yang diberikan Tuhan kepada manusia tidak lepas dari bahan kajian para filosof, baik filosof barat maupun filosof muslim.

Mengingat dengan mengetahui hakikat manusia dan potensi pendidikannya melalui pendekatan filosofis, problema-problema yang menimpa dunia pendidikan khususnya pendidikan Islam bisa terselesaikan atau paling tidak bisa terkurangi terhadap dampak yang ditimbulkannya. Dan untuk lebih terperincinya penjelasan mengenai perspektif filsafat pendidikan Islam tentang manusia dan potensi pendidikannya, maka pemakalah akan mencoba mengantarkan para pembaca menuju pencerahan tentang perspektif filsafat pendidikan Islam tentang manusia dan potensi pendidikannya, yang semua itu akan dijabarkan dalam beberapa sub pembahasan berikut.

\section{Pengertian Filsafat Pendidikan Islam}

Konotasi orang bila mendengar kata filsafat, maka segera akan menunjuk sesuatu yang bersifat prinsip atau dasar. Bahkan selain itu banyak dikaitkan dengan suatu pandangan hidup yang mengandung nilai-nilai dasar tertentu, seperti filsafat Pancasila dan filsafat Islam. Demikan pula dengan filsafat pendidikan Islam.

Filsafat pendidikan Islam adalah gabungan dari 3 kata, yaitu filsafat, pendidikan dan Islam. Sehingga agar kita lebih mudah menyelami pengertian filsafat pendidikan Islam, maka terlebih 
dahulu pemakalah akan menguraikan pengertian dari masingmasing kata tersebut.

\section{Filsafat}

Filsafat berasal dari kata atau bahasa Yunani yaitu philosophia yang tersusun dari kata philein yang berarti cinta, dan sophos yang berarti hikmah (wisdom). Orang Arab kemudian menyesuaikannya ke dalam bahasa mereka dengan menyesuaikannya dengan susunan kata-kata Arab, yaitu falsafa dengan pola fa'lala, fa'lalah dan filal. Dengan demikian, kata benda dari kata kerja falsafa seharusnya menjadi falsafah atau filsaf (Zuhairini, dkk., 2008: 3).

Berdasarkan asal kata dari kata filsafat yaitu philosophia. Dari kata ini kemudian banyak diperoleh pengertian-pengertian filsafat, baik dari segi pengertiannya secara harfiah atau etimologi maupun dari segi kandungan atau terminologi.

Dari pengertian secara etimologi, Harun Nasution memberikan definisi filsafat sebagai pengetahuan tentang hikmah, pengetahuan tentang prinsip-prinsip dasar, mencari kebenaran, membahas dasardasar dari apa yang dibahas. Sehingga ia berpendapat bahwa intisari filsafat ialah berfikir menurut tata tertib (logika) dengan bebas (tidak terikat pada tradisi, dogma serta agama) dan dengan sedalamdalamnya sehingga sampai ke dasar-dasar persoalannya (Zuhairini, dkk., 2008: 4).

Sedangkan Sidi Gazalba yang melihat keragaman pendapat para filosof mengenai pengertian filsafat menyimpulkan dengan menegaskan bahwa kita dapat berfilsafat tentang pengertian filsafat (Zuhairini, dkk., 2008: 5).

\section{Pendidikan}

Pendidikan sebagai usaha membina dan mengembangkan pribadi manusia, yaitu mengembangkan aspek rohaniah dan jasmaniah, berlangsung secara bertahap. Karena memang secara alamiah, manusia tumbuh dan berkembang sejak dalam kandungan sampai meninggal, mengalami proses tahap demi tahap. 
Pendidikan pada hakikatnya adalah mencakup kegiatan mendidik, mengajar dan melatih peserta didik. Istilah mendidik menunjukkan usaha yang lebih ditujukan pada pengembangan budi pekerti, hati nurani, semangat, kecinataan, rasa kesusilaan, ketakwaan dan lain-lain (Usman, 2010: 16).

Dalam kaitan ini, Muchtar Buchori mengemukakan bahwa pendidikan yang baik dan ideal adalah pendidikan yang mempersiapkan peserta didik untuk menghadapi tiga tugas kehidupan, yaitu: untuk dapat hidup (to make living), untuk mengembangkan kehidupan yang bermakna (to lead a meaningful live), dan untuk turut memuliakan kehidupan (to ennoble life) (Usman, 2010: 18).

Mortimer J. Adler seorang tokoh ahli pendidikan di Barat mengartikan pendidikan sebagai proses di mana semua kemampuan manusia (bakat dan kemampuan yang diperoleh) yang dapat dipengaruhi oleh pembiasaan, disempurnakan dengan kebiasaankebiasaan yang baik melalui sarana yang secara artistik dibuat dan dipakai oleh siapa pun untuk membantu orang lain atau dirinya sendiri mencapai tujuan yang ditetapkan, yaitu kebiasaan yang baik (Muzayyin Arifin, 2009: 13). Sedangkan Herman H. Horne berpendapat bahwa pendidikan harus dipandang sebagai suatu proses penyesuaian diri manusia secara timbal balik dengan alam sekitar, dengan sesama manusia, dengan tabi'at tertinggi dari kosmos. John Dewey memandang pendidikan sebagai suatu proses pembentukan kemampuan dasar yang fundamental, baik menyangkut daya pikir (intelektual) maupun daya perasaan (emotional) menuju kearah tabiat manusia (http://mbegedut.blogspot.com/2011/02/pengertian-filsafatpendidikan-menurut.html, diambil tanggal 20 April 2012).

Dari definisi tersebut terlihat jelas bahwa pendidikan harus mampu mengarahkan kemampuan dari dalam diri manusia menjadi suatu kegiatan hidup yang berhubungan dengan Tuhan (Penciptanya), baik kegiatan itu bersifat pribadi maupun kegiatan sosial. 
Bilamana definisi-definisi yang telah disebutkan di atas dikaitkan dengan pengertian pendidikan Islam, akan kita ketahui bahwa pendidikan Islam lebih menekankan pada keseimbangan dan keserasian perkembangan hidup manusia. Sebagaimana pendapatnya Oemar Muhammad Al-Touny al-Syaebani yang mengartikan pendidikan sebagai usaha mengubah tingkah laku individu dalam kehidupan pribadinya atau kehidupan kemasyarakatannya dan kehidupan dalam alam sekitarnya melalui proses kependidikan. Di mana perubahan itu dilandasi dengan nilainilai Islami.

Hasil rumusan Seminar Pendidikan Islam se-Indonesia tahun 1960 juga memberikan pengertian pendidikan Islam sebagai bimbingan terhadap pertumbuhan rohani dan jasmani menurut ajaran Islam dengan hikmah mengarahkan, mengajarkan, melatih, mengasuh dan mengawasi berlakunya semua ajaran Islam.

Berdasarkan definisi pendidikan di atas, maka didapat dikatakan bahwa pendidikan menekankan pada suatu proses yang diinginkan dalam usaha kependidikan adalah proses yang terarah dan bertujuan, yaitu mengarahkan anak didik (manusia) kepada titik optimal kemampuannya (lihat, Zuhairini, dkk., 2008: 10). Sedangkan tujuan yang hendak dicapai adalah terbentuknya kepribadian yang bulat dan utuh sebagai manusai individual dan sosial serta hamba Tuhan yang mengabdikan diri kepada-Nya.

\section{Islam}

Islam sebagai sebuah nama dari nama agama tidak diberikan oleh para pemeluknya melainkan kata "Islam" pada kenyataannya dicantumkan dalam al-Qur'an. Islam berasal dari kata "aslama” yang berarti berserah diri, tunduk dan patuh kepada Allah (Aflatun Muchtar, 2000: 66), artinya manusia dalam berhadapan dengan Tuhannya mengakui akan kelemahannya dan mengakui kemutlakan kekuasaan Tuhan. "salima" berarti menyelamatkan, menentramkan dan mengamankan. Dan "salama" yang berarti menyelamatkan, menentramkan dan mengamankan diri sendiri dan orang lain baik 
dari kata-kata maupun perbuatannya (http://mbegedut.blogspot.com, diambil tanggal 20 April 2012).

Menurut Muhammad Adnan, arti kata Islam ialah: Islam jika diambil dari urutan asal kata "salima" artinya selamat. Islam jika diambil dari urutan asal kata "Sali" artinya damai, rukun, bersatu. Islam jika diambil dari urutan asal kata "istaslama" artinya tunduk, dan taat kepada perintah Allah dengan memakai dasar petunjuk-petunjuk serta bimbingan ajaran Rasul Muhammad SAW. Islam jika diambil dari urutan asal kata "istlasama" artinya tulus dan ikhlas. Islam jika diambil dari urutan asal kata "sullami" artinya tangga untuk mencapai keluhuran derajat lahir dan batin (http://mbegedut.blogspot.com, diambil tanggal 20 April 2012).

Sebagai suatu agama, Islam memiliki ajaran yang diakui lebih sempurna dan kompherhensif dibandingkan dengan agama-agama lainnya yang pernah diturunkan Tuhan sebelumnya. Sebagai agama yang paling sempurna ia dipersiapkan untuk menjadi pedoman hidup sepanjang zaman atau hingga hari akhir. Islam tidak hanya mengatur cara mendapatkan kebahagiaan hidup di akhirat, ibadah dan penyerahan diri kepada Allah saja, melainkan juga mengatur cara mendapatkan kebahagiaan hidup di dunia termasuk di dalamnya mengatur masalah pendidikan. Sumber untuk mengatur masalah pendidikan. Sumber untuk mengatur kehidupan dunia dan akhirat tersebut adalah al-Qur'an dan al-Sunnah. Sebagai sumber ajaran, al-Qur'an sebagaimana telah dibuktikan oleh para peneliti ternyata menaruh perhatian yang besar terhadap masalah pendidikan dan pengajaran.

Jadi bisa dikatakan bahwa Islam adalah suatu ajaran yang bersumber dari Allah Swt., di mana pedoman atau manhaj-nya adalah al-Qur'an dan al-Sunnah guna mencapai keselamatan hidup di dunia dan di akhirat.

Berdasarkan uraian tersebut di atas yang menjelaskan tentang pengertian dari filsafat, pendidikan dan Islam, maka dapat ditarik konklusi bahwa filsafat pendidikan Islam bisa diartikan sebagai studi tentang pandangan filosofis dari sistem dan aliran dalam Islam terhadap masalah-masalah kependidikan dan bagaimana 
pengaruhnya terhadap pertumbuhan dan perkembangan manusia berdasarkan sumber pokok dari ajaran Islam, yaitu al-Qur'an dan al-Sunnah.

Untuk dapat mendidik diri sendiri, pertama-tama manusia harus memahami dirinya sendiri. Apa hakikat manusia, bagaimana hakikat hidup dan kehidupannya. Manusia hidup dalam dunia yang penuh dengan problema kehidupan, maka ia harus mampu menghadapi problema-problema kehidupannya dengan jalan pendidikan. Sekali lagi perlu ditegaskan bahwa filsafat pendidikan Islam mencoba berusaha untuk menjawab semua problema itu dengan pendekatan filosofis pendidikan Islam yang bersumber dari nilainilai ajaran Islam.

\section{Manusia Dalam Pandangan Filsafat Islam}

Pendidikan dapat dikatakan sebagai wujud proses yang dapat membantu pertumbuhan seluruh unsur kepribadian manusia secara seimbang ke arah yang posotif. Pertumbuhan yang demikian hanya terjadi bila ada kesamaan konsep mengenai siapa manusia itu, bagaimana reproduksi dan keberadaannya. Sehingga ketika akan berbicara tentang pendidikan Islam, maka hal pertama yang harus dijelaskan adalah bagaimana konsep manusia menurut pandangan Islam. Sebab konsep itulah yang kemudian akan dijadikan sebagai titik tolak dalam perumusan maupun pengembangan pendidikan Islam (Abd. Halim Soebahar, 2002: 31).

Pemikiran tentang hakikat manusia dibahas dalam falsafah manusia (falsafah al-insaniyah). Pencarian makna diri akan siapa sebenarnya manusia telah lama berlangsung sejak zaman dahulu kala sampai zaman modern sekarang, namun tidak adak kesatuan atau kesepakatan pandangan berbagai teori dan aliran pemikiran mengenai manusia karena melihat dari sudut pandang yang berbeda-beda (Abd. Rahman Assegaf, 2011: 127).

Pemahaman yang tak utuh tentang manusia dapat berakibat fatal bagi perlakuan seseorang terhadap sesamanya. Namun yang jelas bahwa manusia terdiri dari badan dan jiwa harus memenuhi 
kebutuhan-kebutuhan keduanya secara seimbang, agar dapat hidup sejahtera dalam menjalani kehidupannya.

Filsafat Yunani yang diwarisi dari Aristoteles (384-322 SM) yang telah memberikan perhatian kepada jiwa lebih banyak daripada perhatian kepada badan, karena hakikat manusia menurutnya adalah hewan yang berpikir dan berakal, yang membedakan manusia dari hewan ialah bagian dari jwa, yakni pikiran dan akal (Ahmad Fuad Al-Ahwani, 1983: 95; lihat juga Mudji Sutrisno, 1992: 19-20; Moh. Hatta, 1980: 115-118; Harold H. Titus, 1984: 19).

Filsafat juga telah mewarisi suatu hal lain dari orang Yunani, berkenaan dengan filsafat manusia, yaitu penggolongan manusia dalam dua kelompok, kelompok orang-orang khusus dan kelompok orang-orang kebanyakan (al-khashah dan al-'amah). Perbedaan ini mendalam dalam tabi'at manusia, sehingga tidak ada jalan untuk menyamakan manusia antara manusia satu sama lain. Orang-orang khusus ialah mereka yang mengasah akal dengan ilmu-ilmu teoritis, bukan dengan kepandaian praktis. Ringkasnya, pandangan rendah terhadap pekerjaan praktis adalah suatu kenyataan yang benarbenar telah menguasai filsafat Yunani yang diambil oleh para filosof Arab (Ahmad Fuad Al-Ahwani, 1983: 95).

Sejalan dengan perkembangan terhadap persoalan manusia, dewasa ini para ahli menyelidiki manusia dalam berbagai sudut pandang. Ilmu yang menyelidiki dan memandang manusia dari segi fisik disebut Antropologi Fisik. Yang memandang manusia dari sudut pandang budaya disebut Antropologi Budaya. Sedangkan yang memandang manusia dari segi "ada"nya atau dari segi hakikatnya disebut Antropologi Filsafat. Memikirkan dan membicarakan mengenai hakikat manusia inilah yang menyebabkan orang tidak henti-hentinya berusaha mencari jawaban yang memuaskan tentang pertanyaan yang mendasar tentang manusia, yaitu apa, dari mana dan kemana manusia itu (Zuhairini, dkk., 2008: 71).

Menurut Islam, manusia hakikatnya adalah makhluk ciptaan Allah, ia tidaklah muncul dengan sendirinya atau berada oleh dirinya sendiri. Dalam al-Qur'an surat al-Alaq ayat 2, surat alThariq ayat 5, surat ar-Rahman ayat 3 dijelaskan tentang manusia 
yang sesungguhnya diciptakan oleh Allah Swt. Jadi, manusia adalah makhluk ciptaan Allah (Ahmad Tafsir, 2010: 34).

Sebagai makhluk ciptaan Allah, manusia hakikatnya juga merupakan perkaitan antara badan dan ruh. Badan dan ruh masingmasing merupakan substansi yang berdiri sendiri, yang tidak tergantung adanya oleh yang lain. Islam secara tegas mengatakan bahwa kedua substansi yang dua-duanya adalah substansi alam. Sedang alam adalah makhluk. Maka keduanya juga makhluk yang diciptakan oleh Allah Swt. (Zuhairini, dkk., 2008: 71).

Badan (jasmani) dan ruh (rohani) merupakan dua aspek yang tidak dinafikan oleh Islam. Al-Qur'an (lihat QS. Al-Mu'minun [23]: 12-14) dan al-Hadits menjelaskan bahwa manusia itu terdiri dari unsur jasmani (lihat QS. al-Qashash [28]: 77) dan rohani (Ahmad Tafsir, 2010: 44-46). Meskipun Islam memandang manusia dalam dua dimensi, yakni jasad dan ruh atau material dan immaterial (Lihat QS. al-Shaad [38]: 71-72) namun hal ini tidak berarti identik dengan pandangan dualisme-aliran ini berpandangan bahwa manusia pada hakikatnya terdiri dari dua substansi, yaitu jasmani dan rohani, badan dan roh, yang kedua substansi ini masing-masing merupakan unsur asal yang adanya tidak tergantung satu sama lain (lihat Abd. Rachman Assegaf, 2011: 130, dan 171).

Bertolak dari uraian di atas, terlihat bahwa manusia dalam pandangan Islam terdiri dari dua substansi yaitu materi dan immateri. Materi berasal dari bumi dan ruh berasal dari Tuhan. Walaupun dikatakan bahwa substansi materi berasal dari bumi, tetapi hakikatnya berasal dari Tuhan karena sesungguhnya bumi merupakan ciptaan-Nya (berasal dari-Nya). Namun ruh adalah hakikat, dan jasad hanyalah alat yang dipergunakan ruh untuk menjalani kehidupan di alam yang material. Di mana manusia adalah makhluk ciptaan Allah Swt., yang dapat dididik dan mendidik. 


\section{Potensi Dasar Manusia dan Implikasinya Terhadap Pendidikan}

Berdasarkan kesimpulan tentang hakikat manusia yang menegaskan bahwa manusia terdiri dari dua substansi, yaitu substansi jasad/ materi yang merupakan bagian dari alam semesta ciptaan Allah Swt., dan substansi immateri/ ruh yang ditiupkan ke dalam diri manusia sehingga manusia merupakan benda organik yang mempunyai hakikat kemanusiaan serta mempunyai berbagai alat potensial dan fitrah. Atau menurut al-Farabi manusia terdiri atas dua unsur, yaitu unsur dari 'alam al-khalq dan unsur yang berasal dari 'alam al-amr (ruh dari perintah Tuhan) (Muhaimin, 2004: 12).

Manusia yang terdiri atas dua substansi telah dilengkapi dengan alat-alat potensial dan potensi-potensi dasar atau disebut fitrah, yang harus diaktualkan atau ditumbuhkembangkan dalam kehidupan nyata di dunia ini melalui proses pendidikan.

Ditinjau dari segi bahasa, fitrah berarti ciptaan, sifat tertentu yang mana setiap maujud disifati dengannya pada masa awal penciptaannya, sifat pembawaan manusia (yang ada sejak lahir) (Muhaimin, 2004: 16).

Al-Raghib al-Asfahani menjelaskan arti fitrah dari segi bahasa dengan mengungkapkan kalimat "fathara Allah al-khalq" yang maksudnya Allah mewujudkan sesuatu dan menciptakannya bentuk/ keadaan kemampuan melakukan perbuatan-perbuatan. Sedangkan maksud fitrah Allah, sebagaimana yang dijelaskan dalam al-Qur'an (al-Rum [30]: 30) bahwa fitrah adalah suatu kekuatan/ daya untuk mengenal/ mengakui Allah (keimanan kepada-Nya) yang menetap/ menancap di dalam diri manusia. Dengan demikian, makna fitrah adalah suatu kekuatan/ kemampuan (potensi terpendam) yang menetap/ menancap pada diri manusia sejak awal kejadiannya, untuk komitmen terhadap nilai-nilai keimanan kepadaNya, cenderung kepada kebenaran (banif), dan potensi itu merupakan ciptaan Allah Swt. (Muhaimin, 2004: 12).

Potensi juga berarti kemampuan yang mungkin untuk dikembangkan berupa kekuatan, kesanggupan atau daya (KBBI, 
1994: 690; H.M. Taufik, 2012: 58). Lebih lanjut, pengertian dari potensi adalah: kualitas memiliki daya, kemampuan untuk menjalankan daya dan untuk bertindak, kesanggupan atau kemampuan untuk menjadi sesuatu yang mempunyai jenis tertentu. Potensi juga dimaknai sebagai jalan mengada/ mewujudkan atau sesuatu yang memungkinkan terjadi. Potensi dalam hubungannya dengan aksi bisa dipahami sebagai sesuatu yang menyebabkan terjadinya aksi (tindakan) dan menyebabkan terjadinya perubahan (H.M. Taufik, 2012: 58-59).

Bila dilihat dari segi kemampuan dasar paedagogis, manusia dipandang sebagai homo edukandum yaitu makhluk yang harus dididik, atau bisa disebut animal educabil makhluk sebangsa binatang yang bisa dididik (Muzayyin Arifin, 2009: 54). Sehubungan dengan potensi yang dimiliki manusia, manusia memiliki dua potensi, yaitu potensi pasif dan potensi aktif. Potensi pasif merupakan kemampuan untuk menerima sebuah aksi dan disebut potensi murni (tak beraksi) kalau tidak disertai oleh aktualitas manapun dan tidak mengadakan aksi apapun. Sedangkan potensi aktif merupakan kemampuan bawaan untuk menjadi atau untuk menjalankan sesuatu yang spesifik menurut hakikatnya. Potensi aktif ini merupakan kemampuan untuk menghasilkan aksi. Aksi dari potensi aktif, setidak-tidaknya merupakan kegiatan atau aktivitas yang turun dari satu daya (aksi berpikir). Potensi aktif hakikatnya telah ada dalam suatu aksi tertentu. Hal itu dikuatkan dengan prinsip kausalitas, di mana tak seorang pun dapat menghasilkan sesuatu yang belum dia miliki secara tertentu (Loren Bagus, 2000: 872; H.M. Taufik, 2012: 59).

Potensi/ fitrah yang diberikan Tuhan kepada manusia dilengkapi dengan alat-alat potensial manusia yang harus diaktualkan dan atau ditumbuhkembangkan dalam kehidupan nyata di dunia ini melalui proses pendidikan, untuk selajutnya dipertanggungjawabkan di hadapan-Nya kelak di akhirat. Di antara alat-alat potensial tersebut adalah: alat peraba dan alat penciuman (al-lams dan al-syum), alat pendengaran (al-sam'u), penglihatan (al- 
abshar), akal atau daya pikir (al-aq), hati (al-qalb) (Muhaimin, 2004: 12-13).

Bintusi Shati' lebih jauh berpendapat bahwa manusia memiliki karakteristik yang membuatnya pantas menjadi khalifah di bumi, menerima beban taklif, dan amanat kemanusiaan. Karena hanya manusia yang dibekali dengan akal. Asumsinya dibuktikan dengan penelitian di bidang neurobiologi-neurosains bahwa secara potensial otak manusia dibedakan menjadi otak kanan yang mengandung irama, kesadaran ruang, gestalt, imajinasi, melamun, warna, dimensi, inovatif -kreatif. Sedangkan otak kiri ditengarai mengandung potensi kata, logika, angka, urutan, kelinieran, analisis, daftar, matematis. Sehingga otak dapat menghasilkan tiga jenis pikiran: pikiran rasional-intuitif, pikiran emosional dan pikiran spiritual (H.M. Taufik, 2012: 61).

Di samping itu, Syaikh Ahmad Musthafa al-Maraghi menjelaskan bahwa manusia diberi hidayah oleh Allah secara bertingkat-tingkat. Pengertian hidayah di sini, sebagaimana yang dikemukakan oleh Muhammad Rasyid Ridla ialah petunjuk halus yang memudahkan seseorang untuk mencapai sesuatu yang dicari atau mencapai tujuan (Muhaimin, 2004: 14).

Pemberian Tuhan berupa alat-alat potensial dan berbagai potensi dasar atau fitrah manusia tersebut harus ditumbuhkembangkan secara optimal dan terpadu melalui proses pendidikan sepanjang hayatnya. Manusia diberi kebebasan/ kemerdekaan untuk berikhtiar mengembangkan alat-alat potensial dan potensi-potensi dasar/ fitrah manusia tersebut. Namun demikian, dalam pertumbuhan dan perkembangannya tidak bisa dilepaskan dari adanya batas-batas tertentu, yaitu adanya hukumhukum yang pasti dan tetap menguasai alam, hukum yang menguasai benda-benda maupun masyarakat manusia sendiri, yang tidak tunduk dan tidak pula bergantung pada kemauan manusia. Hukum-hukum inilah yang disebut dengan taqdir ("Keharusan Universal" atau "kepastian umum") sebagai batas akhir dari ikhtiar manusia dalam kehidupannya di dunia (Muhaimin, 2004: 19). 
Demikian unik dan pentingnya alat-alat potensial yang dimiliki manusia sebagai fitrah dari Tuhan yang harus ditumbuhkembangkan dalam rangka melaksanakan hakikat pendidikan. Di man pendidikan merupakan suatu proses yang terarah dan bertujuan.

\section{Kesimpulan}

Filsafat pendidikan Islam adalah suatu studi dengan menggunakan pendekatan filosofis dari sistem dan aliran dalam Islam terhadap masalah-masalah kependidikan dan bagaimana pengaruhnya terhadap pertumbuhan dan perkembangan manusia berdasarkan sumber pokok dari ajaran Islam, yaitu al-Qur'an dan al-Sunnah.

Keterkaitan antara sistem berpikir filosofis terhadap persoalan manusia dan potensi pendidikannya telah memberikan corak pemikiran beragam dari para filosof. Sebagian filosof Barat berpandangan bahwa manusia pada hakikatnya terdiri dari dua substansi, yaitu jasmani dan rohani, badan dan roh. Kedua substansi ini masing-masing merupakan unsur asal yang adanya tidak tergantung satu sama lain. Jadi badan tidak bergantung pada ruh, juga sebaliknya ruh tidak berasal dari badan, aliran ini disebut aliran dualisme. Aliran ini menihilkan proses penciptaan, fungsi dan tujuan manusia hidup di dunia yang bersifat transedental.

Lain halnya dengan para pemikir muslim yang menegaskan bahwa manusia adalah makhluk ciptaan Allah, manusia hakikatnya juga merupakan perkaitan antara badan dan ruh. Badan dan ruh masing-masing merupakan substansi yang berdiri sendiri, yang tidak tergantung adanya oleh yang lain. Islam secara tegas mengatakan bahwa kedua substansi yang dua-duanya adalah substansi alam. Sedang alam adalah makhluk. Maka keduanya juga makhluk yang diciptakan oleh Allah Swt. Oleh karena itu, menurut pandangan Islam, manusia terdiri dari dua substansi yaitu materi dan immateri. Materi berasal dari bumi dan ruh berasal dari Tuhan.

Walaupun dikatakan bahwa substansi materi berasal dari bumi, tetapi hakikatnya berasal dari Tuhan karena sesungguhnya bumi 
merupakan ciptaan-Nya (berasal dari-Nya). Namun ruh adalah hakikat, dan jasad hanyalah alat yang dipergunakan ruh untuk menjalani kehidupan di alam yang material. Di mana manusia adalah makhluk ciptaan Allah Swt., yang dapat dididik dan mendidik dengan menumbuhkembangkan potensi/ fitrah yang telah diberikan Allah Swt., kepada manusia dalam menjalani hidup dan kehidupannya.

\section{DAFTAR PUSTAKA}

Abd. Halim Soebahar, Wawasan Baru Pendidikan Islam, Jakarta: Kalam Mulia, 2002.

Abd. Rahman Assegaf, Filsafat Pendidikan Islam, Paradigma Pendidikan Hadhari Berbasis Integratif-Interkonektif, Jakarta:. Rajagrafindo Persada, 2011.

Aflatun Muchtar, Tunduk Kepada Allah, Fungsi dan Peranan Agama dalam Kehidupan Manusia, Jakarta: Khazanah Baru, 2000.

Ahmad Fuad Al-Ahwani, Filsafat Islam, Jakarta: Proyek Pembinaan Prasarana dan Sarana PTA/ IAIN, 1983.

Ahmad Tafsir, Ilmu Pendidikan Dalam Perspektif Islam, Bandung: Remaja Rosdakarya, 2010.

H.M. Taufik, Kreativitas Jalan Baru Pendidikan Islam, Mataram: Leppim IAIN Mataram, 2012.

http://mbegedut.blogspot.com/2011/02/pengertian islammenurut.html,

http:/ / mbegedut.blogspot.com/2011/02/pengertian-filsafat-

pendidikan-menurut.html.

Muhaimin, Paradigma Pendidikan Islam, Upaya Mengefektifkan

Pendidikan Agama Islam di Sekolah, Bandung: Remaja Rosdakarya, 2004.

Muzayyin Arifin, Filsafat Pendidikan Islam, Jakarta: Bumi Aksara, 2009.

Usman, Filsafat Pendidikan, Kajian Filosofis Pendidikan Nabdlatul Watan di Lombok, Yogyakarta: Teras, 2010.

Zuhairini, dkk., Filsafat Pendidikan Islam, Jakarta: Bumi Aksara, 2008. 